\title{
The diet of the black widow spider Latrodectus mirabilis (Theridiidae) in two cereal crops of central Argentina
}

\author{
Gabriel Pompozzi ${ }^{1}$, Nelson Ferretti ${ }^{2}$, Leonela Schwerdt ${ }^{1}$, Sofía Copperi ${ }^{1}$, Adriana A. Ferrero ${ }^{1} \&$ Miguel Simó $^{3}$ \\ 1. Laboratorio de Zoología de Invertebrados II, Departamento de Biología, Bioquímica y Farmacia, Universidad Nacional del Sur, San Juan 670 (8000), Bahía Blanca, Argentina. \\ (gabrielpompozzi@conicet.gov.ar; leo_vane10@hotmail.com; sofia.copperi@uns.edu.ar; aferrero@uns.edu.ar) \\ 2. Centro de Estudios Parasitológicos y de Vectores - CEPAVE (CCT-CONICET) (UNLP), La Plata, Argentina. (nferretti@conicet.gov.ar) \\ 3. Sección Entomología, Facultad de Ciencias, Universidad de la República, Montevideo, Uruguay. (simo@fcien.edu.uy)
}

\begin{abstract}
The spider Latrodectus mirabilis (Holmberg, 1876) is commonly found in cereals crops of central Argentina. We studied its diet composition at the field and capture rate on leaf-cutting ants based on laboratory experiments. This study comprises the first approach that documents the diet of L. mirabilis in wheat and oat fields of central Argentina. We identified 1,004 prey items collected from its webs during the last phenological stages of both cereal crops. The prey composition was variable but the spiders prey mainly on ants (Formicidae, Hymenoptera), who represented more than $86 \%$ of the total. Meanwhile, in the capture rate experiences we registered a high proportion of ants captured by spiders at the beginning of experiences, capturing the half of the ants from total in the first four hours. Summarizing, we reported a polyphagous diet of this spider species in wheat and oat fields. Ants were the most important prey item of this spider, as found in other Latrodectus spiders around the world.
\end{abstract}

KEYWORDS. Diet composition, capture rate, polyphagous predator, South America.

RESUMEN. Dieta de la viuda negra, Latrodectus mirabilis (Theridiidae) en dos cultivos de cereales del centro de Argentina. La araña Latrodectus mirabilis (Holmberg, 1876) se encuentra comúnmente en cultivos de cereales del centro de Argentina. Se estudió la composición de la dieta a campo y la tasa de captura sobre hormigas cortadoras negras a laboratorio. Este estudio documenta el primer registro de la dieta de L. mirabilis en cultivos de trigo y avena del centro de Argentina. Se identificaron 1004 ítem presa colectados de las telas de L. mirabilis en las últimas etapas fenológicas de ambos cultivos. La composición de presas fue variable, pero las arañas se alimentaron principalmente de hormigas (Formicidae, Hymenoptera), las cuales representaban más del 86\% del total de las presas capturadas. A su vez, en las experiencias de tasa de captura, registramos una alta tasa de captura de hormigas al inicio de las mismas, capturando la mitad de las hormigas en las primeras cuatro horas. En resumen, reportamos una dieta polífaga en esta especie de araña en los cultivos de trigo y avena. El ítem presa más importante fueron las hormigas, resultados similares a los encontrados en otras especies del género Latrodectus.

PALABRAS-CLAVE. Composición de dieta, tasa de captura, predador polífago, America del Sur.

Spiders are relevant terrestrial predators and also located on the top of many invertebrate food webs. They are abundant and ubiquitous showing diverse feeding habits (WISE, 1993). Usually, terrestrial food webs have a high diversity of generalist predators, among which spiders are very common (POLIS \& STRONG, 1996). Indeed, they are among the most abundant natural predators registered in agroecosystems (NYFFELER \& BenZ, 1987; NyfFelter \& Sunderland, 2003).

Knowledge of prey items and rates of predation is relevant to evaluate the effect of predators on prey populations and mainly in estimating the potential effectiveness of a predator as an agent of biological control (HAYES \& LOCKLEY, 1990). Most of the spiders are polyphagous predators and are capable to feed on many insects including major crop pests (NYFFELER \& BENZ, 1988). Polyphagy provides access to a variety of nutrients that usually are not obtained through a single prey source, which could enhance growth rates and juvenile survival (ToFT \& WisE, 1999). Nevertheless, few species are specialist of a particular prey, where the well known example is ant-eating spiders (CUSHING, 2012; PeKÁr et al., 2012). It was observed a significant predation on pest species on agroecosystems by spider species belonging to the Theridiidae (RIECHERT \& LOCKLEY, 1984). There are several studies of diet and feeding behavior involving Latrodectus species all over the world (Shulov, 1940; Ross, 1981; MaCKaY, 1982; NyfFeler et al., 1988; Rocha Dias \& Kobler, 1999; HóDAR \& SÁNCHEZ-PIÑERO, 2002; BERTANI et al., 2008; JoHnSON et al., 2011; SALOMON, 2011). However, in Argentina, studies on diet composition and prey selection are scarce; highlighting that from Thomisidae, Lycosidae, Araneidae and Oxyopidae, conducted with species in soybean and alfalfa crops (CHELI et al., 2006; GonZÁlez et al., 2009; Armendano \& GonzÁlez, 2011). Nonetheless, these studies did not involve diet composition at the field. Arguably, they analyzed prey selection or consumption rate at the laboratory or during field experiments. Moreover, in Argentina the knowledge about the natural diet of spiders associated with agroecosystems is unknown.

Latrodectus mirabilis (Holmberg, 1876) is a webbuilding spider with wide distribution on central and southern Argentina, which constructs irregular webs at ground level, and in the cereal crops it lives between grasses and frequently at the entrance of small mammal crevices (ABALOS, 1980). There is abundant in cereal crops, like wheat and oat at southwestern Buenos Aires Province, central Argentina (pers. observ.). However, the only data available of diet for Latrodectus species in this country are based mainly in few observational records (GonZÁlez, 1979; ABALOS, 1980). This previous studies indicate that this species preys on the ants Acromyrmex 
and Camponotus but its degree of spider myrmecophage is still unknown (Abalos, 1980; CusHing, 2012).

Therefore, the main goal of this study was to determine the feeding ecology of the black widow spider in two different crops of central Argentina. The objectives were to examine the diet composition at the field and to estimate the capture rate at the laboratory on leaf-cutting ants (Acromyrmex lundii, Formicidae). We chose this prey species because the ants are the most abundant prey item of Latrodectus spiders in the crops field (see diet composition results below), and because some studies that mention certain preference for this type of prey exist (GonZÁLEZ, 1979). Moreover, Acromyrmex ants cause damage on cereal crops of central Argentina, e.g. sorghum (DANs et al., 2009).

\section{MATERIAL AND METHODS}

The study was conducted in a field crop located at southwestern Buenos Aires province, Argentina $\left(38^{\circ} 20^{\prime} 09^{\prime \prime} \mathrm{S}, 62^{\circ} 42^{\prime} 44^{\prime \prime} \mathrm{W}\right)$. In this area, we studied a winter wheat field and an oat field of 54 ha and 26 ha, respectively. None of the cultivated fields received pesticides during the last 30 years. Both crops were planted in August 2012 (winter in southern hemisphere) and harvested in December of 2012 (beginning of summer in southern hemisphere). The sowing method was conventional, plowing before planting. The study site is located in an area of temperate climate with an annual average temperature of $14^{\circ} \mathrm{C}$ and an annual average rainfall of $670 \mathrm{~mm}$ (obtained from the field owners). The study comprised three sampling dates during November-December (spring) period corresponding to the last phenological stages of crops. Each sample date involved four collectors in active searching during one hour (between $10 \mathrm{am}$ to $3 \mathrm{pm}$ ) for Latrodectus mirabilis webs on each crop. When a web was found, we collected all prey items that had been captured by the spiders. This was achieved by picking the preys off the webs with specialized forceps. Specimens were preserved in $70 \%$ ethyl alcohol. We identified all prey items at the order/family level. Also, we collected spiders (deposited then in 70\% ethyl alcohol) hanging on the web to a more accurate identification. Immature individuals were identified for the color pattern of their abdomen (GonZÁLEZ, 1981). Voucher specimens are deposited in the arachnological collection of Laboratory of Invertebrates II, Universidad Nacional del Sur, Bahía Blanca, Argentina (Nelson Ferretti). We computed the overlap coefficient with the following equation presented by PIANKA (1974): $\alpha=\left(\Sigma \mathrm{p}_{\mathrm{ij}} \mathrm{p}_{\mathrm{ik}}\right) / \sqrt{ }\left(\Sigma \mathrm{p}_{\mathrm{ij}}{ }^{2} \Sigma \mathrm{p}_{\mathrm{ik}}{ }^{2}\right)$, where $p_{\mathrm{ij}}$ and $\mathrm{p}_{\mathrm{ik}}$ represents the proportion of prey items from wheat $\left(\mathrm{p}_{\mathrm{ij}}\right)$ and oat $\left(\mathrm{p}_{\mathrm{ik}}\right)$. Values range between 0 (no overlap) and +1 (complete overlap). Also, we quantified the degree of variation of prey composition using Levins' standardized index of diet breadth, $\mathrm{B}_{\mathrm{A}}=\left(\left(1 / \Sigma \mathrm{p}_{\mathrm{i}}{ }^{2}\right)\right.$ $-1) /(n-1)$, where $p_{i}$ is the proportion of prey items from prey type $\mathrm{i}$, and $\mathrm{n}$ is the total number of prey types (HurlberT, 1978). This index ranges from 0 to 1 , with values close to 0 indicating that a predator consumes few prey types in high proportion, and values close to 1 indicating that all prey are consumed in equal proportion. We calculated $B_{A}$ values for each crop and for the whole study. Moreover, we calculated $B_{A}$ value for each stage of spider. We collected 20 adult females of Latrodectus mirabilis in a not harvested oat field from Chasicó, Argentina, in January 2013. We housed the spiders individually in plastic jars of $14 \times 7.5 \times 3.5 \mathrm{~cm}$ with two metallic rods as support for spider webs. We used a $12 \mathrm{~h}$ light/dark cycle. The room temperature during breeding and experiments was $26.7^{\circ} \mathrm{C} \pm 1.52^{\circ} \mathrm{C}$. We fed the spiders with cockroaches, Blatella germanica Linnaeus, 1767, during two weeks, and then starved for five days in order to standardize the hunger levels prior to experiments. The prey species used in this study was the leaf-cutting ant, Acromyrmex lundii Guérin-Menéville, 1838. We collected 400 worker ants (A. lundii) neighboring university courtyard on the same day that we carried out the experiences. The experiments consisted in a plastic recipient holding one adult female of $L$. mirabilis with 10 individuals of $A$. lundii, and a control recipient which contains 10 ants. We initiated the experience by introducing the ants into the spider recipient and ended after 24 hours. We registered the ants captured by the spider as the dead ants in the control for foreign causes every 4 hours. We estimated the capture rate $(\mathrm{C})$ as $\mathrm{C}=$ $\left(\mathrm{N}_{\mathrm{d}}-\mathrm{N}_{\mathrm{m}}\right) / \mathrm{t}$; where: $\mathrm{N}_{\mathrm{d}}=\mathrm{N}_{0}-\mathrm{N}_{\mathrm{t}}$ represent the number of capture preys by the spider; $\mathrm{N}_{0}$ is the initial number of preys; $\mathrm{N}_{\mathrm{t}}$ is the final number of preys after the $t$ time; $\mathrm{N}_{\mathrm{m}}=\mathrm{N}_{0 \mathrm{c}}-\mathrm{N}_{\mathrm{tc}}$ is the number of dead preys in control; $\mathrm{t}$ is the time in hours.

\section{RESULTS}

We collected 144 spiders in both crops. We registered 3 males, 5 females, 18 immature males, 17 immature females and 101 juveniles of undetermined sex. The juveniles belonged to the VI and VII stages of development (GoNZÁLEZ, 1981). In total we collected and identified 1,004 preys of L. mirabilis. We found nine arthropod orders in the webs of $L$. mirabilis in both fields (Tab. I). The prey composition was variable but the spiders prey mostly on ants (Formicidae, Hymenoptera), which represented more than $86 \%$ of the total (Tab. I). We collected 456 preys in the oat field belonging to 13 item preys of 77 spider's webs (Tab. II). The most abundant item prey was Formicidae whose reach $80.9 \%$, follows by aphiids with $8.6 \%$ (Tab. II). In the wheat field we registered 67 spider's webs and we found 548 preys of 10 item preys (Tab. II). As in oat field, Formicidae, Aphididae and Coleoptera were the most abundant item preys in wheat field, and the spiders fed almost exclusively on ants (Tab. II). In both crop fields, the spiders prey upon natural enemies as Staphylinidae 
(Coleoptera), some Hymenoptera (micro-parasitoids) and other spiders (Araneidae and Lycosidae) in low numbers (Tab. II). The most common preys in the two crops were ants and aphiids, reaching $92.6 \%$ of the total preys. The overlap coefficient was $\alpha=1.006$. The overall diet breadth of $L$. mirabilis at the study site in the two crops was 0.022 (standardized Levin's index, $B_{A}$ ). The $B_{A}$ values for each spider sex ranged from 0 (females) to 0.097 (males). The $\mathrm{B}_{\mathrm{A}}$ values for each spider stage were 0.041 (immature females), 0.046 (immature males) and 0.031 (juveniles). Females showed a zero value of Levin's index because they only prey on ants. The $\mathrm{B}_{\mathrm{A}}$ value on wheat was 0.019 and in oat was 0.041 . We registered a high proportion of ants captured by spiders during the beginning of experiments, capturing $51 \%$ of the total ants in the first four hours (Fig. 1). Two specimens of L. mirabilis consumed all ants during the first four hours. Contrarily, four spiders did not feed on all ants at the end of experiments. After four hours from the initial time, the $\mathrm{C}$ value was 0.83 prey/hour, being $\mathrm{C}=0.69 \mathrm{prey} / \mathrm{hour}$ at the middle of the experience $(12$ hours) and $\mathrm{C}=0.36 \mathrm{prey} / \mathrm{hour}$ when the experience ended (24 hours).

\section{DISCUSSION}

In the present study, some aspects of feeding ecology of Latrodectus mirabilis from two cereal crops of central Argentina are highlighted. We found a varied diet of this spider species in wheat and oat fields. Nine arthropod orders were found in the webs of L. mirabilis in both fields. However, the diet was almost insectivorous and the spiders obtain their primarily sources of prey from two insect orders (Hymenoptera and Hemiptera). From these values, Hymenoptera comprised the majority of prey catches. Within this order, ants were the more relevant item prey of this spider species. Particular prey taxa are often disproportionate represented in the diets of many polyphagous spider species (NyFFELER, 1999), as was found in this study. Other Latrodectus species across different habitats have a polyphagous diet, and has been reported that the prevalent prey type is Coleoptera (Shulov, 1940; HódAR \& SÁNCHEZ-PIÑERO, 2002; Rossi \& Godoy, 2005; Salomon, 2011).

Nevertheless, some Latrodectus spiders like L. pallidus (Pickard-Cambridge 1872) from Israel and L. mactans (Fabricius 1775) from USA, are also important predators of Hymenoptera such ants (Shulov \& Weissmann, 1959; NyfFeler et al., 1988), as was observed in this study. The diet of L. mactans inhabiting cotton field crops in Texas was quite similar to the L. mirabilis diet, were the ants reach the $75 \%$ of the total prey consumed (NyFFeler et al., 1988). Possible explanations of these high values of ants are based on: i) the irregular webs of L. mirabilis, like other theridiid spiders, are adapted primarily for the capture of arthropods that crawl on the ground (LeVI, 2005); ii) the ants represented the most abundant insects in both crops fields (pers. observ.). Diet of juveniles was more diverse than diet of immature males, immature females and adults, preyed on all item preys registered. We found intra-guild predation, but the spiders represent a low percentage in the diet of L. mirabilis, similar to that found in other species of the genus (NYFFELER et al., 1988; SALOMON, 2011). Also, we did not find differences in diet composition between spider that inhabit wheat and oat. The overlap coefficient indicates a complete overlap of preys captured by L. mirabilis between both crops. This could be because both fields had similar available preys.

The low value of the $\mathrm{B}_{\mathrm{A}}$ index indicates that the spiders prey upon a few arthropod orders in high proportion and many orders in small quantities. This low value showed that the diet of $L$. mirabilis could be a specialist, defined as exhibiting narrow diet breadth in a particular environment (NYFFELER, 1999). However, their diet is polyphagous, because the spiders prey upon a varied item prey but with a high proportion of one item (ants). Nevertheless, the black widow spider does not actively select its prey, but has to wait for them to become

Tab. I. Percentage of captured prey by different stages and sex of Latrodectus mirabilis (Holmberg, 1876) in crop fields of central Argentina ( $\mathrm{n}$ is the number of spider webs).

\begin{tabular}{lccccc}
\hline Prey item & Females $(\mathrm{n}=5)$ & Males $(\mathrm{n}=3)$ & Immature Females $(\mathrm{n}=17)$ & Immature Males $(\mathrm{n}=18)$ & Juveniles $(\mathrm{n}=101)$ \\
\hline Insecta & & & & & \\
Formicidae & 100.0 & 91.4 & 88.0 & 90.1 & 83.8 \\
Aphididae & 0 & 0 & 2.4 & 3.9 & 8.4 \\
Coleoptera & 0 & 4.3 & 7.0 & 3.4 & 2.8 \\
Hemiptera & 0 & 0 & 0 & 1.3 & 1.7 \\
Hymenoptera & 0 & 0 & 0 & 0 & 0.8 \\
Diptera & 0 & 4.3 & 0 & 0 & 1.3 \\
Lepidoptera & 0 & 0 & 0 & 0 & 0.2 \\
Orthoptera & 0 & 0 & 0 & 0 & 0.5 \\
Psocoptera & 0 & 0 & 0 & 0.3 \\
Arachnida & 0 & 0 & 0 & 0 & 0.3 \\
Acari & 0 & 0 & 1.3 & 0 & 0.3 \\
Araneae & 100 & 100.0 & 100.0 & 100.0 & 0.2 \\
Total & & & & 0 \\
\hline
\end{tabular}


Tab. II. Prey taxon of Latrodectus mirabilis (Holmberg, 1876) in both crops, central Argentina.

\begin{tabular}{lcc}
\hline Prey taxon & $\begin{array}{c}\text { \% Total number } \\
\text { in oat }\end{array}$ & $\begin{array}{c}\text { \% Total number } \\
\text { in wheat }\end{array}$ \\
\hline Hymenoptera & 80.9 & 90.9 \\
Formicidae & 1.1 & 0.4 \\
Others & & \\
Coleoptera & 0.7 & 0.4 \\
Staphylinidae & 0.2 & 0.2 \\
Curculionidae & 4.0 & 1.8 \\
Others & & \\
Hemiptera & 8.6 & 4.4 \\
Aphididae & 1.5 & 1.1 \\
Others & 0.7 & 0.0 \\
Lepidoptera & 0.4 & 0.2 \\
Orthoptera & 1.1 & 0.2 \\
Diptera & 0.2 & 0.0 \\
Psocoptera & 0.4 & 0.0 \\
Acari & & \\
Araneae & 0.2 & 0.0 \\
Lycosidae & 0.0 & 0.2 \\
Araneidae & 0.0 & 0.2 \\
Other & 100.0 & 100.0 \\
\hline Total & & \\
\hline
\end{tabular}

ensnared by the hunting threads of the web. As a result from this passive hunting mode, the prey captured by the black widow spider reflects the changes in availability (McReynolds \& Polis, 1987). As mentioned above, ants were very abundant in both crops, so they were the most available prey for the spider and this could explain the low value of $\mathrm{B}_{\mathrm{A}}$. Arguably, spider's diet breadth may depend on several factors, including intrinsic factors such as prey-capture behavior and foraging mode, extrinsic factors such as habitat characteristics and prey ecology, and combinations of them (Uetz, 1990). Preycapture behavior can influence the diet breadth in several ways. For example, most spiders, like most arthropod predators, are reluctant to ant predation, because ants are generally aggressive some are venomous and most are simply noxious (CushING, 2012). However, theridiid spiders such as Latrodectus typically capture prey by 'combing' sticky silk around them with their back legs to immobilize the prey (JAPYASSÚ \& CAIRES, 2008). This foraging technique allows capturing large or potentially harmful prey such as ants (NENTwIG, 1987).

Despite that leaf-cutting ants are a noxious prey because they are large and with huge mandibles and spines, we registered a high proportion of ants captured by spiders at the capture rate experience at laboratory. The black widow spiders prey upon ants with no major problems, and captured a high proportion of ants in the first hours of the experience. The daily consumption rate depends on several factors like the spider size, age, sex, physiological events in the life cycle of the spider (e.g. molt), climatic conditions and availability and type of preys (NYFFeler et al., 1994a). NyFFELER et al. (1994b) estimated that a spider in agroecosystems captured

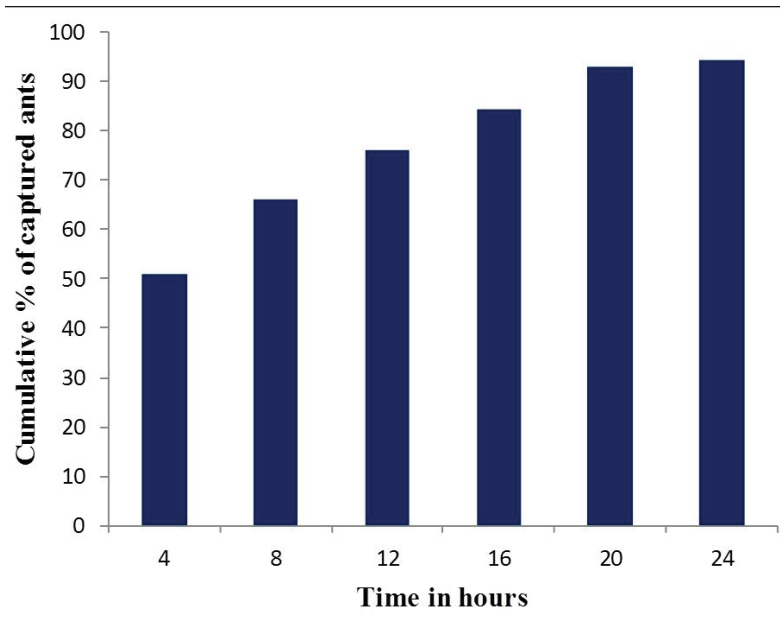

Figure 1. Cumulative percentage of captured ants registered on each interval.

approximately one prey by day. It is very common that the same species feed at a higher rate when prey is offered ad libitum (Young \& LOCKLEY, 1986). This may explains the high capture rates of the black widow spiders in the first hours of our experiences. Nevertheless, the results obtained in this study could allow as thinking in L. mirabilis as an important biological control agent for ants. Although, it is necessary to develop more exhaustive studies, maybe offering different densities of prey and different time of starving to evaluate if exist differences in the capture rate.

The diet of L. mirabilis has not been previously described in detail (ABALOS, 1980). Thus, the results presented here are the first contribution to this spider species. Furthermore, the data presented in this study represent further the diet of juvenile, because more than $70 \%$ of the webs registered belong to immature stages. This is due to the phenological development of crops studied. Wheat and oat are winter crops, and in late spring and early summer are harvested. Adults of $L$. mirabilis appear when the crops are mature, just before the harvested, and because of that we have low data of adult individuals (GoNZÁLEZ, 1981).

Future exhaustive studies should be necessary to include the assessment of the spiders' prey capture rates as well as the evaluation of seasonal population densities of spiders and their prey, since Latrodectus mirabilis comprise a potentially useful species for pest control in cereal crops of central Argentina.

Acknowledgements. Thanks to Dr. Rodrigo Tizón for their help with ants identification. Special thanks to families Copperi and Gutiérrez for allowing us to work in their fields. GP and SC thanks to CONICET for doctoral fellowships, and NF also thanks to CONICET for their postdoctoral fellowship. Financial assistance was provided by the P.G.I. 24/B142 (Universidad Nacional del Sur).

\section{REFERENCES}

AbaLos, J.W. 1980. Las arañas del género Latrodectus en la Argentina. Obras Centenarias del Museo de La Plata 6:29-51. 
ARMENDANo, A. \& GonZÁlez, A. 2011. Efecto de las arañas (Arachnida: Araneae) como depredadores de insectos en cultivos de alfalfa (Medicago sativa) (Favaceae) en Argentina. Revista de Biología Tropical 59(4):1651-1662.

Bertani, R.; Fukushima, C. S. \& Martins, R. 2008. Sociable widow spiders? Evidence of subsociality in Latrodectus Walckenaer, 1805 (Araneae, Theridiidae). Journal of Ethology 26:299-302.

Cheli, G.; Armendano, A. \& González, A. 2006. Preferencia alimentaria de arañas Misumenops pallidus (Araneae: Thomisidae) sobre potenciales insectos presa de cultivos de alfalfa. Revista de Biología Tropical 54(2):505-513.

Cushing, P. E. 2012. Spider-ant associations: An updated review of myrmecomorphy, myrmecophily, and myrmecophagy in spiders. Psyche 2012:1-23.

Dans, D.; Anglada, M. \& Maidana, A. 2009. Caracterización del daño de hormigas cortadoras en el cultivo de sorgo (Sorghum spp). Revista Científica Agropecuaria 13(1):7-15.

GonZÁLEZ, A. 1979. Observaciones bioecológicas sobre una especie del género Latrodectus (Walckenaer 1805) del grupo mactans, de Sierra de la Ventana (Provincia de Buenos Aires, Argentina) (Araneae, Theridiidae): III-Desarrollo post-embrionario. Acta Zoológica Lilloana 35(1):97-110.

1981. Desarrollo postembrionario de Latrodectus mirabilis, Latrodectus corallinus y Latrodectus antheratus (Araneae, Theridiidae). Physis, Sección C, 39(97):83-91.

González, A.; Liljesthröm, G.; Minervino, E.; Castro, D.; GonzÁlez, S. \& Armendano, A. 2009. Predation by Misumenops pallidus (Araneae: Thomisidae) on insects pest of soybean cultures in Buenos Aires Province, Argentina. Journal of Arachnology 37:282-286

HAYES, J. L. \& LOCKLEY, T. C. 1990. Prey and nocturnal activity of wolf spiders (Araneae: Lycosidae) in cotton fields in the delta region of Missisipi. Environmental Entomology 19(5):1512-1518.

Hódar, J. A. \& Sánchez-Piñero, F. 2002. Feeding habits of the blackwidow spider Latrodectus lilianae (Araneae: Theridiidae) in an arid zone of south-east Spain. Journal of Zoology 257:101109 .

HURLBERT, S. H. 1978. The measurement of niche overlap and some relatives. Ecology 59:67-77.

JAPYASSÚ, H. F. \& CAIRES, R. A. 2008. Hunting tactics in a cobweb spider (Araneae -Theridiidae) and the evolution of behavioral plasticity. Journal of Insect Behavior 21:258-284.

Johnson, A.; Revis, O. \& Chadwick-Johnson, J. 2011. Chemical prey cues influence the urban microhabitat preferences of Western black widow spiders, Latrodectus hesperus. Journal of Arachnology 39:449-453.

Levi, H. W. 2005. Theridiidae. In: Ubick, D.; Paquin, P.; Cushing, P. \& Roтн, V. eds. Spiders of North America: an identification manual. USA, American Arachnological Society. p. 235-243.

MaCKAY, W. P. 1982. The effect of predation of western widow spiders (Araneae: Theridiidae) on harvester ants (Hymenoptera: Formicidae). Oecologia 53:406-411.

McReynolds, C. N. \& Polis, G. A. 1987. Ecomorphological factors influencing prey use by two sympatric species of orb-weaving spiders, Argiope aurantia and Argiope trifasciata. Journal of Arachnology 15:371-384.

Nentwig, W. 1987. The prey of spiders. In: Nentwig, E. ed. Ecophysiology of Spiders. Springer-Verlag, Berlin, Germany. p. 249-263.

NYFFeLER, M. 1999. Prey selection of spiders in the field. Journal of Arachnology 27:317-324.
NyfFeler, M. \& BenZ, G. 1987. Spiders in natural pest control: a review. Journal of Applied Entomology 103:321-339.

1988. Feeding ecology and predatory importance of wolf spiders (Pardosa spp.) (Araneae, Lycosidae) in winter wheat fields. Journal of Applied Entomology 106:123-134.

NyFFELLER, M. \& SundeRLAND, D. K. 2003. Composition, abundance and pest control potential of spider communities in agroecosystem. A comparison of European and U.S. studies. Agriculture, Ecosystem and Environment 95:579-612.

NyfFeller, M.; DeAn, D. A. \& Sterling, W. L. 1988. The southern black widow spider, Latrodectus mactans (Araneae, Theridiidae), as a predator of the red imported fire ant, Solenopsis invicta (Hymenoptera, Formicidae), in Texas cotton fields. Journal of Applied Entomology 106:52-57.

Nyffeller, M.; Sterling, W. L. \& Dean, D. A. 1994a. How spiders make a living. Environmental Entomology 23:1357-1367.

1994b. Insectivorous activities of spiders in United States fields crops. Journal of Applied Entomology 118:113-128.

Pekár, S.; Coddington, J. A. \& Blackledge, T. A. 2012. Evolution of stenophagy in spiders (Araneae): evidence based on the comparative analysis of spider diets. Evolution 66(3):776-806.

PianKa, E. R. 1974. Niche overlap and diffuse competition. Proceedings of the National Academy of Sciences 71(5):2141-2145.

Polis, G. A. \& Strong, D. R. 1996. Food web complexity and community dynamics. American Naturalist 147:813-846.

RIECHERT, S. \& LOCKLEY, T. 1984. Spiders as biological control agents. Annual Review of Entomology 29:299-320.

Rocha Dias, M. F. \& Kobler, T. 1999. Comportamento e padrão alimentar de uma espécie de Latrodectus do grupo Mactans (Araneae, Theridiidae) em cativeiro. Revista Brasileira de Zoologia 16(4):991-996.

Ross, K. G. 1981. Report of necrophagy in the black widow spider, Latrodectus hesperus (Araneae: Theridiidae). Journal of Arachnology 9:109.

Rossi, M. N. \& Godoy, W. A. C. 2005. Web contents of Nesticodes rufipes and Latrodectus geometricus (Araneae: Theridiidae) in a Brazilian poultry house. Journal of Entomological Science 40:347-351.

SALOMON, M. 2011. The natural diet of a polyphagous predator, Latrodectus hesperus (Araneae: Theridiidae), over one year. Journal of Arachnology 39:154-160.

Shulov, A. 1940. On the biology of two Latrodectus spiders in Palestine. Proceedings of the Linnean Society of London 152:309-328.

Shulov, A. \& Weissmann, A. 1959. Notes on the life habits of the venom of the three Latrodectus spiders species of Israel. Ecology 40:515-518

TofT, S. \& Wise, D.H. 1999. Growth, development, and survival of a generalist predator fed single- and mixed-species diets of different quality. Oecologia 119:191-197.

UETZ, G. W. 1990. Prey selection in web-building spiders and evolution of prey defenses. In: Evans, D. L. \& SCHMIDT, J. O. eds. Insect defenses: adaptive mechanisms and strategies of prey and predators. New York, State University of New York Press. p. 93-128.

Wise, D. H. 1993. Spiders in Ecological Webs. Cambridge, Cambridge University Press. 328p.

YounG, O. P. \& LOCKLEY, T. C. 1986. Predation of striped of lynx spider, Oxyopes salticus (Araneae: Oxyopidae), on tarnished plant bug; Lygus lineolaris (Heteroptera: Miridae): a laboratory evaluation. Annals of the Entomological Society of America 79:879-883. 